\title{
Stage I Digestive System Neuroendocrine Tumor AJCC v7
}

National Cancer Institute

\section{Source}

National Cancer Institute. Stage I Digestive System Neuroendocrine Tumor A/CC V7. NCI

Thesaurus. Code C88028.

Stage I includes: T1, N0, M0. T1: Stomach: tumor invades lamina propria or submucosa and is $1 \mathrm{~cm}$ or less in size; duodenum /jejunum/ileum: tumor invades lamina propria or submucosa and is $1 \mathrm{~cm}$ or less in size; ampulla: tumor $1 \mathrm{~cm}$ or less; colon or rectum: tumor invades lamina propria or submucosa and is $2 \mathrm{~cm}$ or less. N0: No regional lymph node metastasis. M0: No distant metastasis. (AJCC 7th ed.) 